Florea : Jurnal Biologi dan Pembelajarannya, 8(2), 2021, 69-81

This is an open access article under the CC-BY-SA license (https://creativecommons.org/licenses/by-sa/4.o/)

ISSN 2355-6102(print), ISSN 2502-0404(online)

DOI : 10.25273/florea.v8i2.11049

\title{
KOMPOSISI DAN LUAS RELUNG MAKANAN IKAN PALUNG (Hampala macrolepidota C.V.1823) DI WADUK PB. SOEDIRMAN BANJARNEGARA, JAWA TENGAH
}

\author{
Elsa Melisa $^{1)}$, Asrul Sahri Siregar ${ }^{2)}$, dan Siti Rukayah ${ }^{3)}$ \\ 1,2 Program Studi Manajemen Sumberdaya Perairan-Fakultas Perikanan dan Ilmu Kelautan, \\ Universitas Jenderal Soedirman, Purwokerto \\ 3 Jurusan Biologi-Fakultas Biologi, Universitas Jenderal Soedirman, Purwokerto \\ 1 Email : elsa.melisa@mhs.unsoed.ac.id \\ 2 Email : asrul_sir@yahoo.com \\ 3 Email : siti.rukayah@unsoed.ac.id
}

Naskah diterima......, dan disetujui ......

\begin{abstract}
This study aims to determine the composition and value of the natural feed niche of trough fish caught from the waters of the PB Reservoir. Sudirman. The research method used is a survey method with a sampling technique using purposive random sampling. The research location was divided into three stations, namely I (Karang Kemiri), II (Wanadadi), and III (Karang Jambe). Sampling was carried out three times (19 February, 07 March, and 2 August 2020). Data were analyzed descriptively comparatively. The results showed that the composition of the trough fish diet was dominated by Chlorophyta and plant debris. Based on the selectivity index and the most significant part of trough fish, including omnivorous fish. Large trough fish have a high food niche area. Small, medium and large trough fish have stiff competition for food in the waters.
\end{abstract}

Kata kunci : Natural feed, composition, niche area, trough fish, PB reservoir. Sudirman.

\section{PENDAHULUAN}

Waduk Panglima Besar Soedirman (PB. Soedirman) terletak di Jawa Tengah. Tujuan utama pembangunan Waduk PB irigasi, kegiatan domestik, pengendali ban. Soedirman adalah untuk Pembangkit Listrik Tenaga Air (PLTA), dengan pemanfaatan lainnya sebagai jir, obyek wisata, dan kegiatan perikanan (Wulandari, 2007). Jenis ikan spesies asli yang ditemukan di waduk PB. Soedirman salah satunya adalah ikan palung (Hampala macrolepidota C.V.1823) (Rukayah dan Wibowo, 2010). Ikan palung adalah ikan asli golongan karnivora yang dijadikan sebagai salah satu ikan target tangkapan di Waduk PB. Soedirman.

Selain perikanan tangkap, terdapat kegiatan lain yaitu budidaya Keramba Jaring Apung (KJA). Kegiatan ini menyebabkan penurunan kualitas air, karena adanya sisa-sisa pakan intensif dengan padat tebar tinggi. Kondisi perairan seperti ini memberikan suatu tekanan terhadap ikan yang hidup di dalamnya terutama spesies penumpukan kotoran dari hasil budidaya asli seperti ikan palung. Kelangsungan penting demi menjaga kelestariannya. Oleh karena itu penelitian ini dilakukan bertujuan untuk mengetahui dan menentukan komposisi dan luas relung makanan ikan palung di Waduk PB. Soedirman atau yang lebih dikenal hidup spesies asli ikan palung sangat dengan istilah analisis isi lambung. Analisis terhadap isi lambung ikan merupakan kajian tentang hubungan antara komposisi pakan alami dalam lambung dan habitatnya (pakan alami di perairan), baik yang bersifat planktonik, bentik, nektonik maupun yang lainnya (Siregar et al., 2007). yang tidak termakan oleh ikan dan

\section{METODE PENELITIAN}

Penelitian ini dilakukan pada bulan Februari-Agustus 2020 di Waduk PB. Soedirman Kabupaten Banjarnegara, Jawa Tengah. Teknik pengambilan sampel 
menggunakan Purpossive Random Sampling. Lokasi pengambilan sampel dibagi menjadi tiga stasiun yaitu, I (Karang Kemiri), II (Wanadadi), dan III (Karang Jambe). Penentuan stasiun pengambilan sampel didasarkan pada kondisi lingkungan di Waduk PB. Soedirman.

\section{Parameter Penelitian}

Parameter yang diamati pada penelitian ini yaitu obyek ikan (panjang dan berat tubuh, volume lambung, jumlah individu pakan alami dalam lambung dan di perairan, serta keragaman genera pakan alami dalam lambung dan di perairan). Obyek air (penetrasi cahaya, temperatur, kekeruhan, $\mathrm{pH}, \mathrm{O}_{2}$ terlarut, $\mathrm{COD}$, $\mathrm{CO}_{2}$ bebas, dan amonia).

\section{Pengambilan dan Pengawetan Sampel Ikan Palung}

Pengambilan sampel ikan palung dilakukan sebanyak tiga kali pada bulan Februari, Maret, dan Agustus. Pengambilan sampel ikan dibantu oleh nelayan menggunakan jaring insang (gillnet) kemudian disimpan dalam ice box dan diberi es batu sebagai pengawet.

\section{Pengambilan dan Pengawetan Sampel Pakan Alami dalam Lambung}

Sampel ikan palung yang telah diukur panjang dan beratnya kemudian dibedah untuk diambil lambungnya. Proses pembedahan dilakukan dengan menggunakan gunting bedah, dimulai dari anus menuju bagian atas perut sampai ke bagian belakang operculum kemudian menurun kearah ventral hingga ke dasar perut. Sampel pakan kemudian dimasukkan ke dalam botol sampel lalu diawetkan menggunakan formalin $4 \%$ sebanyak $1 \mathrm{ml}$ dan lugol sebanyak 3 tetes.

\section{Identifikasi dan Perhitungan Pakan Alami dalam Lambung}

Sampel isi lambung dihomogenkan dan diambil sebanyak tiga tetes untuk diletakkan diatas objek glass lalu ditutup dengan cover glass. Sampel diamati di bawah mikroskop sebanyak 30 lapang pandang. Kemudian diidentifikasi menggunakan buku Davis (1955), Edmondson (1963), Sachlan (1982), dan
APHA (2017). Kelimpahan pakan alami dihitung menggunakan rumus modifikasi dari Lackey Drop Microtransent Counting (APHA, 1989) yaitu $\mathrm{F} \times \mathrm{N}$.

$$
F=\frac{Q 1}{Q 2} \times \frac{V 1}{V 2} \times \frac{1}{P} \times \frac{1}{W}
$$

Keterangan:

$\mathrm{N}$ :Jumlah pakan alami rataan pada setiap preparat

$\mathrm{Q}_{1}$ :Luas gelas penutup

$\mathrm{Q}_{2}$ :Luas lapang pandang

$\mathrm{V}_{1}$ :Volume air dalam botol sampel

$\mathrm{V}_{2}$ :Volume air dibawah gelas penutup

$\mathrm{P}$ :Jumlah lapang pandang yang diamati

W :Volume lambung ikan palung

\section{Pengambilan dan Pengawetan Sampel Pakan Alami di Perairan}

Sampel air diambil sebanyak 100L menggunakan ember plastik berukuran 5L diulangi hingga 20 kali, kemudian disaring menggunakan plankton net No. 25 ukuran mata jaring $65 \mu \mathrm{m}$. Sampel air dalam botol penampung plankton net dipindahkan kedalam botol sampel berukuran $30 \mathrm{ml}$. Kemudian ditambahkan larutan 4\% dan lugol sebanyak 3 tetes lalu diberi kertas label, di dinginkan dalam ice box, lalu diamati di laboratorium.

\section{Identifikasi dan Perhitungan Pakan Alami di Perairan}

Sampel air dihomogenkan hingga merata dan air sampel diambil sebanyak tiga tetes menggunakan pipet kemudian sampel diamati menggunakan mikroskop perbesaran $10 \times 10$ sebanyak 30 titik lapang pandang. sampel pakan alami diidentifikasi menggunakan buku Davis (1955), Edmondson (1963), Sachlan (1982), dan APHA (2017).

Kelimpahan pakan alami yang ditemukan dihitung menggunakan rumus modifikasi dari Lackey Drop Microtransent Counting (APHA, 1989) yaitu $\mathrm{F} \times \mathrm{N}$.

Keterangan:

$$
F=\frac{Q 1}{Q 2} \times \frac{V 1}{V 2} \times \frac{1}{P} \times \frac{1}{W}
$$

$\mathrm{N}$ :Jumlah pakan alami rataan pada setiap preparat 
$\mathrm{Q}_{1}$ :Luas gelas penutup

$\mathrm{Q}_{2}$ :Luas lapang pandang

$\mathrm{V}_{1}$ : Volume air dalam botol penampung

$\mathrm{V}_{2}$ :Volume air dibawah gelas penutup

$\mathrm{P}$ :Jumlah lapang pandang yang diamati

W :Volume air yang disaring

\section{Pengambilan dan Pengawetan Sampel Air}

Sampel air diukur secara insitu (langsung diukur di lapangan) yang meliputi penetrasi cahaya, temperatur, $\mathrm{O}_{2}$ terlarut, $\mathrm{CO}_{2}$ bebas dan secara eksitu (dimasukkan kedalam ice box dan diukur di laboratorium) yang meliputi sampel ikan, kekeruhan, pH, COD, dan amonia.

\section{Pengumpulan Data}

\section{1) Panjang, Berat, dan Volume Lambung}

a. Panjang dan Berat Ikan

Panjang total ikan di ukur dari ujung mulut sampai ujung ekor menggunakan mistar ukur (penggaris). Berat total ikan di timbang menggunakan timbangan digital.

b. Volume Lambung

Volume lambung ikan palung diukur dengan cara melihat kenaikan volume air pada gelas ukur yang sudah diisi air.

\section{2) Indeks Selektivitas}

Indeks Selektivitas digunakan untuk mengetahui perbandingan antara organisme pakan alami yang terdapat dalam lambung dengan organisme pakan alami di perairan (Effendie, 1979), Rumus untuk menghitung indeks selektivitas sebagai berikut:

Keterangan:

$$
\mathrm{E}=\frac{\mathrm{ri}-\mathrm{pi}}{\mathrm{ri}+\mathrm{pi}}
$$

E : indeks selektivitas

ri : jumlah relatif pakan alami dalam lambung pi : jumlah relatif pakan alami di perairan.

\section{3) Indeks Bagian Terbesar}

Analisis data untuk menentukan jenis dan komposisi makanan menggunakan indeks bagian terbesar (Natarajan \& Jhingran 1961), yaitu :

$$
I_{i}=\frac{V_{i} \times O_{i}}{\sum_{i}^{n}\left(V_{i} \times O_{i}\right)} \times 100
$$

Keterangan:

Ii : Indeks bagian terbesar

Vi : Persentase volume makanan jenis ke-I

Oi : Persentase frekuensi kejadian makanan jenis ke-I,

$\mathrm{N}$ : Jumlah total organisme makanan $(\mathrm{i}=1,2$, $3, \ldots . . \mathrm{n})$

\section{4) Luas Relung (B)}

Luas relung makanan dihitung dengan rumus indeks Levins (Krebs 1989)

$$
\mathrm{B}=\frac{1}{\Sigma \mathrm{P}_{\mathrm{j}}^{2}} \quad \mathrm{P}_{\mathrm{j}}=\frac{\mathrm{N}_{\mathrm{j}}}{\mathrm{Y}}
$$

Keterangan:

$\mathrm{B}$ :Luas relung makanan Levins

$\mathrm{Pj}$ :Proporsi makanan ke-j yang ditemukan atau dimanfaatkan oleh ikan

$\mathrm{Nj}$ :Jumlah individu pada makanan ke-j

$\mathrm{Y}$ : Jumlah total makanan $(\Sigma \mathrm{Nj})$

Pembakuan nilai luas relung makanan agar bernilai $0-1$ dihitung menggunakan rumus perhitungan Hulbert (1978) in Krebs (1989):

$$
B_{\mathrm{A}}=\frac{\mathrm{B}-1}{\mathrm{n}-1}
$$

Keterangan:

$\mathrm{B}_{\mathrm{A}}$ : pembakuan luas relung makanan Levins $(0-1)$

B : luas relung makanan Levins

$\mathrm{N}$ : jumlah organisme makanan yang

dimanfaatkan

\section{5) Tumpang Tindih Relung (CH)}

Analisis tumpang tindih relung makanan menggunakan indeks Morisita yang telah disederhanakan oleh Horn (Krebs 1989), yaitu :

$$
\mathrm{CH}=\frac{2 \Sigma_{\mathrm{i}}^{\mathrm{n}}\left(\mathrm{P}_{\mathrm{ij}} \times \mathrm{P}_{\mathrm{ik}}\right)}{\sum_{\mathrm{i}}^{\mathrm{n}} \mathrm{P}_{\mathrm{ij}}^{2}+\Sigma_{\mathrm{i}}^{\mathrm{n}} \mathrm{P}_{\mathrm{ik}}^{2}}
$$

Keterangan:

$\mathrm{CH}$ : Tumpang tindih relung

Pij : Proporsi jenis organisme makanan ke-i yang dimanfaatkan kelompok ikan ke-j

Pik : Proporsi jenis organisme makanan ke-i yang dimanfaatkan kelompok ikan ke-k 
Elsa Melisa, Asrul Sahri Siregar, dan Siti Rukayah

$\mathrm{N}$ :Jumlah total organisme makanan 


\section{HASIL DAN PEMBAHASAN}

\section{Gambaran Umum, Deskripsi Area dan Sebaran Frekuensi Panjang}

Waduk PB. Soedirman terletak pada koordinat $109^{0} 06^{\prime} 00^{\prime \prime}-110^{\circ} 07^{\prime} 49^{\prime \prime}$ BT dan $7^{0} 17^{\prime} 04^{\prime \prime}-7^{0} 47^{\prime} 07^{\prime \prime}$ LS. Berdasarkan fungsinya Waduk PB. Soedirman merupakan waduk serbaguna. Waduk serbaguna umumnya dimanfaatkan sebagai pembangkit listrik, penyedia air untuk irigasi, pengendali banjir, pariwisata, dan sarana produksi perikanan (Rukayah dan Wibowo, 2010).

Ikan palung yang tertangkap di waduk PB. Soedirman berjumlah 31 ekor. Ikan yang telah di ukur panjang dan berat tubuhnya kemudian di kelompokkan secara statistik menjadi 3 kategori ukuran yaitu kecil (I), sedang (II), dan besar (III). Kelompok ukuran panjang ikan palung tersaji pada tabel 1 .

Tabel 1. Kelompok ukuran panjang ikan palung yang tertangkap di Waduk PB. Soedirman

\begin{tabular}{cccc}
\hline Kelompok & Jumlah & Kisaran Panjang $(\mathrm{cm})$ & Ketarangan \\
\hline I & 6 & $\mathrm{X}<15,0$ & Kecil \\
II & 20 & $15,0 \leq \mathrm{X} \leq 27,2$ & Sedang \\
III & 5 & $\mathrm{X}>27,2$ & Besar \\
\hline
\end{tabular}

Berdasarkan Tabel 1. ikan palung ukuran kecil berjumlah 6 ekor dengan kisaran panjang kurang dari $15,0 \mathrm{~cm}$, ikan palung ukuran sedang berjumlah 20 ekor dengan kisaran panjang antara 15,0-27,2 cm, dan ikan palung ukuran besar berjumlah 5 ekor dengan kisaran panjang kurang $15,0 \mathrm{~cm}$.

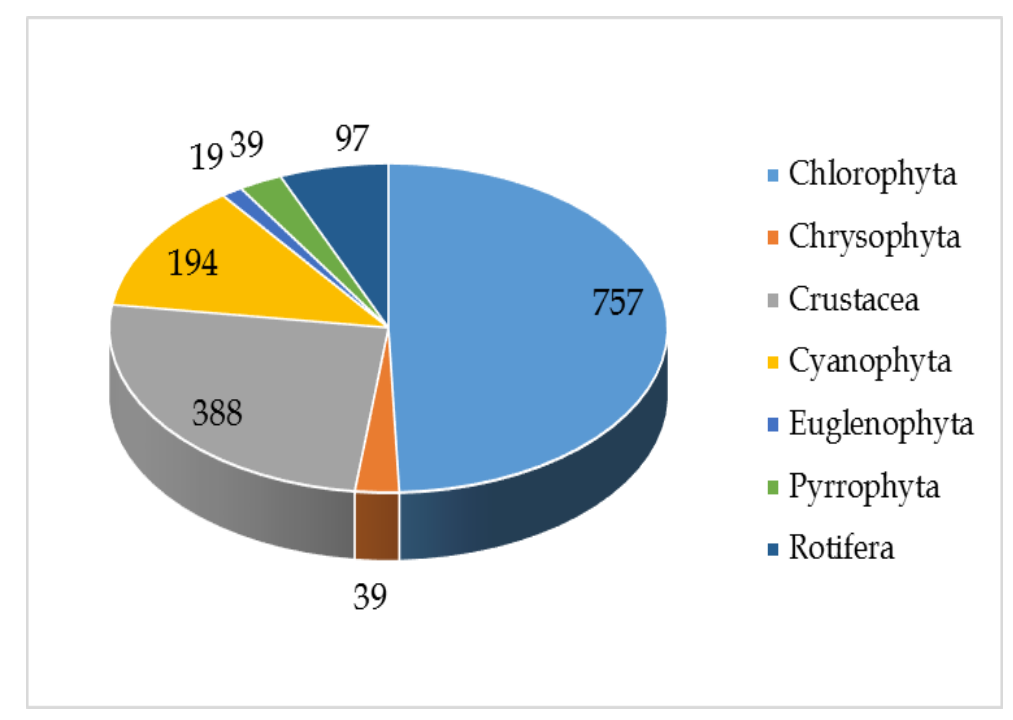

Gambar 1. Kelimpahan (Ind/l) pakan alami di Waduk PB. Soedirman

Berdasarkan Gambar 1. kelimpahan pakan alami di perairan Waduk PB. Soedirman sebesar 1.533 Ind/1 dari 20 genera yang ditemukan. Prosentase kelimpahan Chlorophyta 49,37\%, Chrysophyta 2,53\%, Crustacea $25,32 \%$, Cyanophyta $12,66 \%$, Euglenophyta $1,27 \%$, Pyrrophyta $2,53 \%$, dan Rotifera $6,33 \%$. Kelompok tumbuhan (fitoplankton) memiliki nilai prosentase yang lebih besar yaitu $68,35 \%$ dibandingkan dengan kelompok hewan yang hanya $31,65 \%$.

Kelimpahan fitoplankton perairan Waduk PB. Soedirman cukup tinggi karena perairan tersebut termasuk kategori eutrofik mendekati hipereutrofik. Hal tersebut dikemukakan oleh Widyastuti et al. (2015) yang menyatakan bahwa Tingginya kadar nutrien yang terdapat di perairan Waduk PB. Soedirman berasal dari kegiatan budidaya 
keramba jaring apung atau budidaya intensif dengan padat tebar tinggi, aktivitas holtikultura di hulu sungai Serayu dan buangan limbah rumah tangga.

Jumlah genera pakan alami yang ditemukan dalam lambung ikan palung diketahui sebanyak 9 genera. Informasi mengenai keragaman genera yang ditemukan dalam lambung ikan palung ditampilkan pada Tabel 2.

Tabel 2. Jumlah genera pakan alami dalam lambung ikan palung pada setiap kelompok ukuran yang diperoleh selama penelitian

\begin{tabular}{clccc}
\hline \multirow{2}{*}{ No. Divisi/Filum } & \multicolumn{3}{c}{ Ukuran ikan } \\
\cline { 3 - 5 } A & Kelompok Tumbuhan & Kecil & Sedang & Besar \\
1 & Chlorophyta & 1 & 3 & 3 \\
2 & Chrysophyta & 0 & 2 & 2 \\
3 & Cyanophyta & 1 & 0 & 0 \\
4 & Serpihan tumbuhan & $\geq 1$ & $\geq 3$ & $\mathbf{3}$ \\
Jumlah & Kelompok Hewan & $\mathbf{2}$ & $\mathbf{5}$ & $\mathbf{5}$ \\
1 & Annelida & 0 & 1 & 1 \\
2 & Crustacea & 1 & 0 & 0 \\
3 & Protozoa & 1 & 0 & $\geq 1$ \\
4 & Serpihan hewan & $\geq 1$ & $\mathbf{2}$ & $\mathbf{2}$ \\
& Jumlah & $\mathbf{2}$ & $\mathbf{1}$ & $\mathbf{7}$ \\
\hline
\end{tabular}

Berdasarkan Tabel 2. keragaman pakan alami dalam lambung ikan palung ukuran kecil terdiri dari kelompok tumbuhan (Chlorophyta, Cyanophyta, dan serpihan tumbuhan) dan kelompok hewan (Crustacea, Protozoa, dan serpihan hewan). Ikan palung ukuran sedang terdiri dari kelompok tumbuhan (Chlorophyta, Chrysophyta, dan serpihan tumbuhan) dan kelompok hewan (Annelida dan serpihan hewan). Ikan palung ukuran besar terdiri dari kelompok tumbuhan (Chlorophyta, Chrysophyta, dan serpihan tumbuhan) dan kelompok hewan (Annelida, Crustacea dan serpihan hewan).

Ketiga kelompok ukuran ikan memiliki nilai keragaman pakan alami yang berbeda. Ikan palung kecil tidak didominasi oleh salah satu kelompok pakan, sedangkan ikan palung sedang dan besar didominasi oleh kelompok tumbuhan. Selanjutnya data kelimpahan pakan alami lambung ikan palung yang tertangkap di perairan Waduk PB. Soedirman disajikan pada tabel 3 .

Tabel 3. Kelimpahan individu dan relatif (\%) pakan alami dalam lambung ikan palung pada setiap kelompok ukuran yang diperoleh selama penelitian

\begin{tabular}{clrrrrrr}
\hline \multirow{2}{*}{ No Genera } & \multicolumn{2}{c}{ Kecil } & \multicolumn{2}{c}{ Sedang } & \multicolumn{2}{c}{ Besar } \\
\cline { 3 - 7 } & Klp & KR (\%) & Klp & KR (\%) & Klp & KR (\%) \\
\hline A & Kelompok Tumbuhan & & & & & & \\
1 & Chlorophyta & 133 & 8,33 & 154 & 8,08 & 709 & 30,14 \\
2 & Chrysophyta & 0 & 0,00 & 369 & 19,37 & 198 & 8,42 \\
3 & Cyanophyta & 33 & 2,07 & 0 & 0,00 & 0 & 0,00 \\
4 & Serpihan tumbuhan & 798 & 50,00 & 614 & 32,23 & 482 & 20,49 \\
& & $\mathbf{9 6 4}$ & $\mathbf{6 0 , 4 0}$ & $\mathbf{1 1 3 7}$ & $\mathbf{5 9 , 6 9}$ & $\mathbf{1 3 8 9}$ & $\mathbf{5 9 , 0 6}$ \\
B & Kelompok Hewan & & & & & & \\
1 & Annelida & 0 & 0,00 & 31 & 1,63 & 28 & 1,19 \\
2 & Crustacea & 166 & 10,40 & 0 & 0,00 & 113 & 4,80 \\
3 & Protozoa & 67 & 4,20 & 0 & 0,00 & 57 & 2,42
\end{tabular}




\begin{tabular}{rrrrrrrr}
4 & & 399 & 25,00 & 737 & 38,69 & 765 & 32,53 \\
& Jumlah & $\mathbf{6 3 2}$ & $\mathbf{3 9 , 6 0}$ & $\mathbf{7 6 8}$ & $\mathbf{4 0 , 3 1}$ & $\mathbf{9 6 3}$ & $\mathbf{4 0 , 9 4}$ \\
& Total & $\mathbf{1 5 9 6}$ & $\mathbf{1 0 0 , 0 0}$ & $\mathbf{1 9 0 5}$ & $\mathbf{1 0 0 , 0 0}$ & $\mathbf{2 3 5 2}$ & $\mathbf{1 0 0 , 0 0}$ \\
\hline
\end{tabular}

Klp = Kelimpahan, $\mathrm{KR}=$ Kelimpahan Relatif $(\%)$

Berdasarkan Tabel 3. kelimpahan pakan alami dalam lambung ikan palung ukuran kecil sebesar $1.596 \mathrm{Ind} / 2,12 \mathrm{ml}$ yang terdiri dari kelompok tumbuhan $964 \mathrm{Ind} / 2,12 \mathrm{ml}(60,4 \%)$ dan kelompok hewan $632 \mathrm{Ind} / 2,12 \mathrm{ml}(39,6 \%)$. Ikan palung ukuran sedang mempunyai kelimpahan sebesar $1.905 \mathrm{Ind} / 2,71 \mathrm{ml}$ yang terdiri dari kelompok tumbuhan $1.137 \mathrm{Ind} / 2,71$ $\mathrm{ml}(59,7 \%)$ dan kelompok hewan $768 \mathrm{Ind} / 2,71$ $\mathrm{ml}(40,3 \%)$. Ikan palung ukuran besar mempunyai kelimpahan sebesar 2.352 Ind/3,66 ml yang terdiri dari kelompok tumbuhan 1.389 Ind/3,66 ml (59,1\%) dan kelompok hewan 963 Ind/3,66 ml (40,9\%).

Kelimpahan pakan alami dalam lambung pada setiap kelompok ukuran ikan berbeda-beda, namun baik ikan palung kecil, sedang, maupun besar umumnya didominasi oleh kelompok tumbuhan (fitoplankton) yaitu lebih dari 50\%. Tingginya nilai kelimpahan fitoplankton dalam lambung ikan sebanding dengan kondisi perairan di Waduk PB. Soedirman yang merupakan perairan eutrofik, sehingga hal tersebut dimanfaatkan oleh ikan palung untuk lebih banyak mengkonsumsi fitoplankton daripada pakan alami yang lainnya.

\section{Indeks Selektivitas dan Bagian Terbesar Ikan Palung}

Perhitungan indeks selektivitas dilakukan dengan cara membandingkan prosentase kelimpahan pakan dalam lambung dengan prosentase kelimpahan pakan di perairan. Pakan alami yang ditemukan dalam lambung ikan palung dipilih dan digemari atau tidak berdasakan nilai indeks selektivitas. Terdapat 3 kategori nilai indeks selektivitas, yaitu Jika nilai E positif maka terjadi pemilihan pakan, nilai $\mathrm{E}$ negatif maka tidak terjadi pemilihan pakan, dan nilai $\mathrm{E}=0$ berarti tidak ada seleksi ikan terhadap pakan (Effendi, 1997). Nilai indeks selektivitas ikan palung pada setiap kelompok ukuran disajikan pada table

Tabel 4. Indeks selektivitas ikan palung yang diperoleh selama penelitian

\begin{tabular}{|c|c|c|c|c|c|c|c|c|c|c|c|c|c|c|}
\hline \multirow{2}{*}{ No. } & \multirow{2}{*}{ Divisi/Filum } & \multirow{2}{*}{$\mathrm{p}$} & \multicolumn{3}{|c|}{$\mathbf{r}$} & \multicolumn{3}{|c|}{$\mathrm{I}$} & \multicolumn{3}{|c|}{ II } & \multicolumn{3}{|c|}{ III } \\
\hline & & & $\mathrm{I}$ & II & III & ri & pi & $\mathrm{E}$ & ri & pi & $\mathrm{E}$ & ri & pi & $\mathrm{E}$ \\
\hline A & Golongan Tumbuhan & & & & & & & & & & & & & \\
\hline 1 & Chlorophyta & 757 & 133 & 154 & 709 & 8.33 & 49.37 & -0.71 & 8.08 & 49.37 & -0.72 & 30.14 & 49.37 & -0.24 \\
\hline 2 & Chrysophyta & 39 & 0 & 369 & 198 & 0.00 & 2.53 & -1.00 & 19.37 & 2.53 & 0.77 & 8.42 & 2.53 & 0.54 \\
\hline 3 & Cyanophyta & 194 & 33 & 0 & 0 & 2.07 & 12.66 & -0.72 & 0.00 & 12.66 & -1.00 & 0.00 & 12.66 & -1.00 \\
\hline 4 & Euglenophyta & 19 & 0 & 0 & 0 & 0.00 & 1.27 & -1.00 & 0.00 & 1.27 & -1.00 & 0.00 & 1.27 & -1.00 \\
\hline 5 & Pyrrophyta & 39 & 0 & 0 & 0 & 0.00 & 2.53 & -1.00 & 0.00 & 2.53 & -1.00 & 0.00 & 2.53 & -1.00 \\
\hline 6 & Serpihan tumbuhan & 0 & 798 & 614 & 482 & 50.00 & 0.00 & 1.00 & 32.23 & 0.00 & 1.00 & 20.49 & 0.00 & 1.00 \\
\hline B & Golongan Hewan & & & & & & & & & & & & & \\
\hline 1 & Annelida & 0 & 0 & 31 & 28 & 0.00 & 0.00 & 0.00 & 1.63 & 0.00 & 1.00 & 1.19 & 0.00 & 1.00 \\
\hline 2 & Crustacea & 388 & 166 & 0 & 113 & 10.40 & 25.32 & -0.42 & 0.00 & 25.32 & -1.00 & 4.80 & 25.32 & -0.68 \\
\hline 3 & Protozoa & 0 & 67 & 0 & 57 & 4.20 & 0.00 & 1.00 & 0.00 & 0.00 & 0.00 & 2.42 & 0.00 & 1.00 \\
\hline 4 & Rotifera & 97 & 0 & 0 & 0 & 0.00 & 6.33 & -1.00 & 0.00 & 6.33 & -1.00 & 0.00 & 6.33 & -1.00 \\
\hline 5 & Serpihan hewan & 0 & 399 & 737 & 765 & 25.00 & 0.00 & 1.00 & 38.69 & 0.00 & 1.00 & 32.53 & 0.00 & 1.00 \\
\hline & Jumlah & 1533 & 1596 & 1905 & 2352 & 100.00 & 100.00 & & 100.00 & 100.00 & & 100.00 & 100.00 & \\
\hline
\end{tabular}

P: kelimpahan pakan alami di perairan, r: kelimpahan pakan alami dalam lambung, pi: kelampihan relatif pakan alami di perairan, ri: kelimpahan relatif pakan alami dalam lambung 
Berdasarkan Tabel 4. indeks selektivitas ikan palung ukuran kecil cenderung melakukan pemilihan positif pada Divisi/Filum Protozoa, serpihan hewan, dan serpihan tumbuhan. Cenderung melakukan pemilihan negatif pada Divisi/Filum Chlorophyta, Chrysophyta, Cyanophyta, Euglenophyta, Pyrrophyta, Crustacea, dan Rotifera. Ikan palung ukuran kecil melakukan pemilihan positif terhadap 1 genus kelompok tumbuhan dan 2 genera kelompok hewan. Pemilihan positif terhadap ketiga genera tersebut bernilai sama $(+1,00)$.

Indeks selektivitas ikan palung ukuran sedang cenderung melakukan pemilihan positif pada Divisi/Filum Chrysophyta, Annelida, serpihan tumbuhan dan serpihan hewan. Cenderung melakukan pemilihan negatif pada Divisi/Filum Chlorophyta, Cyanophyta, Euglenophyta, Pyrrophyta, Crustacea, dan Rotifera. Ikan palung ukuran sedang melakukan pemilihan positif terhadap 2 genera kelompok tumbuhan dan 2 genera kelompok hewan. Pemilihan positif terhadap keempat genera tersebut bernilai $+1,00$ (Annelida, serpihan tumbuhan, serpihan hewan) dan $+0,77$ (Chrysophyta).

Indeks selektivitas ikan palung ukuran besar cenderung melakukan pemilihan positif terhadap Divisi/Filum Chrysophyta, Annelida, Protozoa, serpihan tumbuhan dan serpihan hewan. Cenderung melakukan pemilihan negatif terhadap Divisi/Filum Chlorophyta, Cyanophyta, Euglenophyta, Pyrrophyta, Crustacea, dan Rotifera. Ikan palung ukuran besar melakukan pemilihan positif terhadap 2 genera kelompok tumbuhan dan 3 genera kelompok hewan. Pemilihan positif terhadap kelima genera tersebut bernilai $+1,00$ (Annelida, Protozoa, serpihan tumbuhan, serpihan hewan) dan $+0,54$ (Chrysophyta).

Berdasarkan analisis indeks selektivitas pakan alami, diketahui bahwa ikan palung kecil melakukan pemilihan positif terhadap 3 genera, ikan sedang melakukan pemilihan positif terhadap 4 genera, dan ikan besar melakukan pemilihan positif terhadap 5 genera.

Pakan alami ikan dapat dibedakan menjadi 3 kategori, yaitu makanan utama, pelengkap, dan tambahan. Makanan utama adalah makanan yang ditemukan dalam lambung dengan jumlah banyak, makanan pelengkap ditemukan dalam jumlah sedikit dan makanan tambahan ditemukan dalam jumlah sangat sedikit. Berdasarkan kriteria, jika IP $>25 \%$ termasuk kategori makanan utama, IP 4$25 \%$ kategori makanan pelengkap, dan IP <4\% kategori makanan tambahan (Effendie, 1979). Indeks bagian terbesar pakan alami ikan palung disajikan pada tabel 5.

Tabel 5. Indeks bagian terbesar pakan alami ikan palung pada setiap kelompok ukuran yang diperoleh selama penelitian

\begin{tabular}{|c|c|c|c|c|c|}
\hline \multirow{2}{*}{ No. } & \multirow{2}{*}{ Genera } & & \multicolumn{3}{|c|}{$\mathrm{IP}(\%)$} \\
\hline & & & Kecil & Sedang & Besar \\
\hline $\mathbf{A}$ & Kelompok Tumbuhan & & & & \\
\hline 1 & Chlorophyta & & 4,8 & 5,3 & 23,5 \\
\hline 2 & Chrysophyta & & 0.0 & 12,7 & 4,4 \\
\hline 3 & Cyanophyta & & 0,4 & 0,0 & 0,0 \\
\hline 4 & Serpihan tumbuhan & & 58,1 & 37,1 & 26,6 \\
\hline & & Jumlah & 63,3 & 55,1 & 54,5 \\
\hline B & Kelompok Hewan & & & & \\
\hline 1 & Annelida & & 0,0 & 0,3 & 0,3 \\
\hline 2 & Crustacea & & 6,0 & 0,0 & 2,5 \\
\hline 3 & Protozoa & & 1,6 & 0,0 & 0,6 \\
\hline 4 & Serpihan hewan & & 29,0 & 44,6 & 42,2 \\
\hline & & Jumlah & 36,6 & 44,9 & 45,6 \\
\hline & & Total & 100,0 & 100,0 & 100,0 \\
\hline
\end{tabular}

$\mathrm{IP}=$ indeks bagian terbesar $(\%)$

Berdasarkan Tabel 5. indeks bagian terbesar pakan alami ikan palung ukuran kecil memiliki makanan utama berupa serpihan tumbuhan $(58,1 \%)$ dan serpihan hewan $(29 \%)$, (C) 2021 Florea: Jurnal Biologi dan Pembelajarannya | 76 
makanan pelengkap berupa Chlorophyta $(4,8 \%)$ dan Crustacea $(6,0 \%)$, serta makanan tambahan berupa Cyanophyta $(0,4 \%)$ dan Protozoa $(1,6 \%)$. Ikan palung ukuran sedang memiliki makanan utama berupa serpihan tumbuhan $(37,1 \%)$ dan serpihan hewan $(44,6 \%)$, makanan pelengkap berupa Chlorophyta $(5,3 \%)$ dan Chrysophyta (12,7\%), serta makanan tambahan berupa Annelida $(0,3 \%)$. Ikan palung ukuran besar memiliki makanan utama berupa serpihan tumbuhan $(26,6 \%)$ dan serpihan hewan (42,2\%), makanan pelengkap berupa Chlorophyta $(23,5 \%)$ dan Chrysophyta $(4,4 \%)$, serta makanan tambahan berupa Annelida $(0,3 \%)$, Crustacea $(2,5 \%)$, dan Protozoa $(0,6 \%)$. Ketiga kelompok ukuran ikan memiliki makanan utama berupa serpihan tumbuhan dan serpihan hewan. Berdasarkan hasil analisis dapat disimpulkan bahwa ikan palung di Waduk PB. Soedirman merupakan ikan omnivora.

\section{Luas Relung Makanan Ikan Palung}

Analisis luas relung makanan dilakukan untuk melihat jumlah sumberdaya makanan yang dimanfaatkan oleh ikan. Luas relung makanan menggambarkan keragaman makanan yang dimanfaatkan oleh suatu organisme (Oktaviani, 2006). Luas relung makanan ikan palung berdasarkan kelompok ukuran panjang disajikan pada Tabel 6.

Tabel 6. Luas relung pakan alami ikan palung pada setiap kelompok ukuran yang diperoleh selama penelitian

\begin{tabular}{clccc}
\hline \multirow{2}{*}{ No. Genera } & \multicolumn{3}{c}{$\mathrm{Pj}^{2}$} \\
\cline { 3 - 4 } & \multicolumn{1}{c}{ Kecil } & Sedang & Besar \\
\hline $\mathbf{A}$ & Kelompok Tumbuhan & 0,0069 & 0,0065 & 0,0909 \\
1 & Chlorophyta & 0,0004 & 0,0375 & 0,0071 \\
2 & Chrysophyta & & & \\
3 & Cyanophyta & 0,2500 & 0,1039 & 0,0420 \\
4 & Serpihan tumbuhan & & & 0,0001 \\
B & Kelompok Hewan & & 0,0003 & 0,0023 \\
1 & Annelida & 0,0108 & & 0,0006 \\
2 & Crustacea & 0,0018 & & 0,1058 \\
3 & Protozoa & 0,0625 & 0,1497 & $\mathbf{0 , 2 4 8 8}$ \\
4 & Serpihan hewan & $\mathbf{0 , 3 3 2 5}$ & $\mathbf{0 , 2 9 7 9}$ & $\mathbf{4 , 0 2}$ \\
& $\quad$ Jumlah & $\mathbf{3 , 0 1}$ & $\mathbf{3 , 3 6}$ & $\mathbf{0 , 5 0}$ \\
\hline
\end{tabular}

$\mathrm{Pj}=$ Proporsi makanan ke-j yang dimanfaatkan oleh ikan

Berdasarkan Tabel 6. diketahui bahwa nilai luas relung makanan ikan palung ukuran kecil 3,01 dengan standarisasi 0,40. Ikan palung ukuran sedang 3,36 dengan standarisasi 0,59. Ikan palung ukuran besar 4,02 dengan standarisasi 0,50. Nilai luas relung tertinggi terdapat pada ikan palung ukuran besar dan luas relung terendah terdapat pada ikan palung ukuran kecil. Hal tersebut menunjukkan bahwa ikan palung ukuran besar $(>27,2 \mathrm{~cm})$ memilih makanan yang lebih beragam dibandingkan ikan palung ukuran kecil $(<15 \mathrm{~cm})$ dan sedang $(15,0-27,2 \mathrm{~cm})$.

Ikan palung ukuran besar memiliki nilai luas relung yang tinggi, karena pada ukuran tersebut ikan palung memanfaatkan sumberdaya makanan yang beragam dan dikonsumsi dalam jumlah yang relatif sama (seimbang). Ikan dengan luas relung makanan tertinggi/terbesar memiliki jenis makanan yang lebih beragam dibandingkan dengan ikan yang memiliki luas relung kecil (Satia et al., 2011).

Faktor yang mempengaruhi nilai luas relung makanan adalah jenis kelamin dan ukuran ikan. Semakin besar ukuran panjang ikan, maka pola kebiasaan makan juga akan berubah dan akan menggunakan luas relung yang besar (Izzani, 2012). 


\section{Tumpang Tindih Relung Makanan Ikan Palung}

Kriteria nilai tumpang tindih relung terdiri dari 3 kelompok, yaitu peluang terjadinya kompetisi rendah $(<0,33)$, peluang terjadinya kompetisi sedang $(0,33-0,67)$, dan peluang terjadinya kompetisi tinggi $(>0,67)$ (Moyle dan Senanayake, 1984). Jika nilai tumpang tindih berkisar 1, maka kedua kelompok yang dibandingkan memiliki jenis makanan yang sama. Jika nilai tumpang tindih sama dengan nol, maka tidak didapatkan makanan yang sama diantara dua kelompok yang dibandingkan (Colwell et al., 1971). Tumpang tindih relung makanan ikan palung disajikan pada Tabel 7 .

Tabel 7. Tumpang tindih relung pakan alami ikan palung pada setiap kelompok ukuran yang diperoleh selama penelitian

\begin{tabular}{cccc}
\hline \multirow{2}{*}{ Kelompok Ukuran Ikan } & \multicolumn{3}{c}{ Tumpang Tindih Relung } \\
\cline { 2 - 3 } & Kecil & Sedang & Besar \\
Kecil & & \\
Sedang & 0,88 & 0,91 \\
Besar & 0,96 & \\
\hline
\end{tabular}

Berdasarkan Tabel 7. dapat diketahui bahwa nilai tumpang tindih relung makanan ikan palung antara ikan kecil dengan ikan sedang 0,88; antara ikan kecil dengan ikan besar 0,96; dan antara ikan sedang dengan ikan besar 0,91. Nilai tumpang tindih relung terendah terdapat pada kelompok ukuran ikan kecil dengan ikan sedang, sedangkan tumpang tindih relung tertinggi terdapat pada kelompok ukuran ikan kecil dengan ikan besar.

Perhitungan lengkap tumpang tindih relung dapat dilihat pada lampiran 12 . Berdasarkan kriteria yang dikemukakan oleh Moyle dan Senanayake (1984), ketiga kelompok ikan palung di Waduk PB. Soedirman baik kecil, sedang, maupu besar termasuk dalam kriteria memiliki kompetisi tinggi karena bernilai lebih dari 0,67. Tingginya nilai tumpang tindih relung makanan menunjukkan bahwa ikan tersebut memiliki persaingan yang sangat ketat antar kelompok ukuran. Hal ini diduga karena ikan tersebut menyukai makanan yang sama. Nilai tumpang tindih relung makanan yang rendah disebabkan karena makanan yang dimanfaatkan pada kelompok ikan berbeda, sehingga akan mengurangi persaingan antar kelompok dalam memanfaatkan sumberdaya makanan yang terdapat dalam perairan (Nurnaningsih et al., 2005).

\section{Kondisi Habitat Ikan Palung}

Kondisi limnologis suatu perairan perlu diketahui hubungannya dengan keberadaan ikan-ikan yang bernilai ekonomis tinggi (Siregar et al., 2008). Pengukuran kualitas air sebagai tolok ukur kondisi habitat ikan palung di Waduk PB. Soedirman dilakukan pada bulan Maret dan Agustus 2020. Hasil pengukuran kualitas air di perairan Waduk PB. Soedirman disajikan pada Tabel 8.

Table 8. Kualitas perairan di Waduk PB. Soedirman

\begin{tabular}{clccc}
\hline \multirow{2}{*}{ No. } & \multicolumn{1}{c}{ Parameter } & Satuan & Maret & Bulan \\
\cline { 4 - 5 } & & $\mathrm{cm}$ & $32-60$ & Agustus \\
\hline 1 & Penetrasi Cahaya & ${ }^{0} \mathrm{C}$ & $28-30$ & $80-150$ \\
2 & Temperatur & $\mathrm{NTU}$ & - & $29-35,5$ \\
3 & Kekeruhan & $\mathrm{unit}$ & 7,0 & $0,53-8,99$ \\
4 & $\mathrm{pH}$ & $\mathrm{mg} / 1$ & $1,80-2,50$ & 7,0 \\
5 & $\mathrm{O}_{2}$ terlarut & $\mathrm{mg} / 1$ & $0,38-0,46$ & $6,00-12,40$ \\
6 & $\mathrm{CO}_{2}$ Bebas & &
\end{tabular}




\begin{tabular}{lllcr}
7 & COD & $\mathrm{mg} / \mathrm{l}$ & - & $0,33-0,63$ \\
8 & Amonia & $\mathrm{mg} / \mathrm{l}$ & $0,04-0,06$ & $0,04-0,07$ \\
\hline
\end{tabular}

Berdasarkan Tabel 8. penetrasi cahaya yang didapat pada pengukuran bulan Maret berkisar antara 32-60 $\mathrm{cm}$ dengan rataan $45,50 \pm 14,03 \mathrm{~cm}$ dari kedalaman $170-315 \mathrm{~cm}$ dengan rataan $238,00 \pm 72,92 \mathrm{~cm}$, sedangkan pada bulan Agustus berkisar antara 80-150 cm dengan rataan $106,67 \pm 37,86 \mathrm{~cm}$ dari kedalaman 80-250 cm dengn rataan $168,33 \pm 85,20 \mathrm{~cm}$. Penetrasi cahaya yang kurang dari $25 \mathrm{~cm}$ dapat membahayakan biota (Kordi dan Tancung, 2005).

Temperatur pada bulan Maret berkisar antara $28-30{ }^{\circ} \mathrm{C}$ dengan rataan $28,67 \pm 1,15{ }^{\circ} \mathrm{C}$ dan pada bulan Agustus berkisar antara 29$35,50{ }^{\circ} \mathrm{C}$ dengan rataan $31,67 \pm 3,40{ }^{\circ} \mathrm{C}$. Kriteria baku mutu temperatur air yang mendukung untuk kelangsungan hidup biota akuatik berkisar antara $29-32{ }^{0} \mathrm{C}$ (PP No.82, 2001). Kisaran temperatur yang diperoleh pada bulan Agustus sedikit lebih tinggi dari standar baku mutu, karena pada waktu tersebut merupakan puncak musim kemarau sehingga menyebabkan temperatur perairan meningkat. Awal musim hujan tahun 2020 dimulai pada bulan Oktober (Ridwan, 2020).

Kekeruhan berkisar antara 0,53-8,99 NTU dengan rataan $3,35 \pm 4,88$ NTU, merupakan kondisi normal. Kekeruhan yang masih mendukung usaha perikanan adalah kurang dari 50 NTU (Wardoyo, 1981). Nilai pH yang telah diukur pada bulan Maret dan Agustus di semua stasiun ialah 7,0. Perairan dengan nilai $\mathrm{pH}$ antara 6,5-7,5 merupakan perairan normal yang masih memenuhi syarat untuk suatu kehidupan biota (Wardhana, 2004).

$\mathrm{O}_{2}$ terlarut pada bulan Maret berkisar antara 1,80-2,50 mg/l dengan rataan 2,23 $\pm 0,38$ $\mathrm{mg} / \mathrm{l}$, sedangkan pada bulan Agustus berkisar antara 6,00-12,40 $\mathrm{mg} / \mathrm{l}$ dengan rataan $8,25 \pm 3,60 \mathrm{mg} / \mathrm{l}$. Kandungan $\mathrm{O}_{2}$ terlarut minimum adalah $2 \mathrm{mg} / \mathrm{l}$ dalam keadaan nornal dan tidak tercemar oleh senyawa beracun. Kandungan $\mathrm{O}_{2}$ terlarut minimum tersebut sudah cukup mendukung kehidupan organisme (Swingle, 1968).
$\mathrm{CO}_{2}$ bebas pada bulan Maret berkisar antara 0,38-0,46 mg/l dengan rataan $0,41 \pm 0,04$ mg/l, sedangkan pada bulan Agustus berkisar antara TT-6,85 mg/l dengan rataan 3,46 $\pm 3,43$ $\mathrm{mg} / \mathrm{l}$. Kadar karbondioksida yang baik bagi organisme perairan yaitu kurang dari $15 \mathrm{mg} / \mathrm{l}$ (Idrus, 2018).

Kadar COD berkisar antara 0,33-0,63 $\mathrm{mg} / \mathrm{l}$ dengan rataan $0,45 \pm 0,16 \mathrm{mg} / \mathrm{l}$. Konsentrasi COD yang memenuhi syarat untuk kegiatan perikanan sebesar $20-37 \mathrm{mg} / \mathrm{l}$, peningkatan nilai COD mengindikasikan banyaknya senyawa kimiawi yang ada di dalam perairan dan sebaliknya penurunan nilai COD mengindikasikan rendahnya senyawa kimiawi yang ada di dalam perairan (Pudjiastuti, 2013).

Amonia yang baik untuk kelangsungan hidup ikan kurang dari $1 \mathrm{mg} / \mathrm{l}$ (Asmawi, 1983). Keberadaan amonia dalam air dapat menyebabkan daya ikat oksigen oleh butir-butir darah pada tubuh ikan berkurang, sehingga dapat menurunkan nafsu makan (Andrianto, 2005). Kandungan amonia yang terukur di perairan Waduk PB. Soedirman pada bulan Maret berkisar antara 0,04 - 0,06 mg/l dengan rataan $0,05 \pm 0,01 \mathrm{mg} / \mathrm{l}$ sedangkan pada bulan Agustus berkisar antara $0,04-0,07 \mathrm{mg} / \mathrm{l}$ dengan rataan $0,05 \pm 0,02 \mathrm{mg} / \mathrm{l}$. Nilai tersebut masih dapat ditoleransi oleh biota ikan karena kurang dari $1 \mathrm{mg} / \mathrm{l}$.

\section{KESIMPULAN}

1. Komposisi pakan alami di perairan Waduk PB. Soedirman didominasi oleh Chlorophyta sedangkan komposisi dalam lambung ikan palung di dominasi oleh Chlorophyta dan serpihan tumbuhan.

2. Indeks selektivitas ikan palung ukuran besar memiliki pemilihan jenis pakan yang beragam dibandingkan ikan palung ukuran lain. Berdasarkan indeks bagian terbesar (IP), baik ikan palung kecil, sedang, maupun besar memiliki makanan utama berupa serpihan tumbuhan dan serpihan hewan sehingga termasuk ikan omnivora. 
3. Luas relung makanan tertinggi terdapat pada ikan palung ukuran besar dan luas relung terendah terdapat pada ikan palung ukuran kecil. Berdasarkan tumpang tindih relung baik ikan palung kecil, sedang, maupun besar memiliki persaingan yang ketat terhadap pemanfaatan makanan di perairan.

4. Habitat ikan palung di Waduk PB. Soedirman umunya dalam kondisi baik sehingga mendukung kehidupan biota ikan dan organisme akuatik yang lain seperti pakan alami.

\section{DAFTAR PUSTAKA}

Asmawi, S. 1983. Pemeliharaan Ikan dalam Keramba. Gramedia Jakarta. 62.

Colwell, 1.C. and Futuyma, D.J. (1971). On the Measurement of Niche Breadth and Overlap. Ecology, 32: 567-576.

Davis, C.C. (1955). The Marine and FreshWater Plankton. Michigan State University Press, United States of America.

Edmondson, W.T. (1963). Fresh-Water Biology. University of Washington, United States of America.

Effendi, I. (1997). Biologi Perikanan. Yayasan Pustaka Nusantara Yogyakarta.Oktaviani, I. 2006. Studi Kebiasaan Makanan Ikan Terbang (Hirundichtys oxycephlmus) di Perairan Binuangeun, Kabupaten Lebak, Propinsi Banten. Skripsi. Manajemen Sumberdaya Perairan, Fakultas Perikanan dan Ilmu Kelautan, Institut Pertanian Bogor. 45 .

Effendie, M.I. (1979). Metode Biologi Perikanan. Yayasan Dwi Sri Bogor. 112.

Idrus, S.W.A. (2018). Analisis Kadar Karbondioksida di Sungai Ampenan
Andrianto, T.T. (2005). Pedoman Praktis Budidaya Ikan Nila. Absolut Yogyakarta. 200.

American Public Health Association (APHA). (1989) Standard Methods for The Examination of Waters and Wastewater. 17th ed. American Public Health Association, American Water Works, Water ollution Control Federation. Washington, D.C. 1467.

A(2017). Standard Methods for Examination of Water and Wastewater. 23th ed. American Public Health Association. Washington, DC. 15

Lombok. Jurnal Pijar MIPA, 13(2): 167-170.

Izzani, N. (2012). Kebiasaan Makanan Ikan Tembang (Sardinella fimbriata Cuvier and Valenciennes 1847) dari Perairan Selat Sunda yang Didaratkan di PPP Labuan, Kabupaten Pandeglang, Banten. Skripsi. Departemen Manajemen Sumberdaya Perairan Fakultas Perikanan dan Ilmu Kelautan, Institut Pertanian Bogor. 51.

Kordi, M.G dan Tancung, A.B. (2005). Pengelolaan Kualitas Air. Penerbit Rineka Cipta Jakarta. 208.

Krebs, C.J. (1989). Ecological Methodology. Harper and Row Publisher. New York. 652.

Moyle, P.B. and Senanayake, F.R. (1984). Resource Partitioning among The Fishes of Rainforest Streams in Sri Lanka. J. Zool. Lond, 202: 195-223.

Natarajan, A.V. And Jhingran, A. G. (1961). Index of Preponderance a Method of Grading The Food Element in The Stomach of Fishes. Indian J. Fish, 8(1): 54-59.

Nurnaningsih, Rahardjo, M.F., Sukimin, S. (2005). Pemanfaatan Makanan Oleh 
Ikan-ikan Dominan di Perairan Waduk Ir. H. Djuanda [Utilization of Food by Dominant Fishes at Ir. H. Djuanda Reservoir]. Jurnal Iktiologi Indonesia, 4(2): 61-65.

Peraturan Pemerintah (PP) Nomor 82. (2001). Pengelolaan Kualitas Air dan Pengendalian Pencemaran Air.

Pudjiastuti, I. (2013). Perbedaan Kadar BOD dan COD Sebelum dan Sesudah Pengoahan di RSUD Karanganyar. Jurnal Program D IV Kesehatan Kerja, Fakultas Kedokteran Universitas Sebelas Maret, Surakarta.

Ridwan, M (BMKG). (2020). Analisis Iklim: Prakiraan Musim Hujan Tahun 2020/2021 di Indonesia. https://www.bmkg.go.id/iklim/prakira an-musim.bmkg. Diunduh pada 3 November 2020

Rukayah, S. dan Wibowo, D.N. (2010). Komposisi Spesies Ikan Introduksi pada Ekosistem Waduk Oligotrof (Acuan: untuk Konservasi Ikan Indigenous). Prosiding Seminar Nasional Biologi. Universitas Negeri Semarang.

Sachlan, M. (1982). Planktonologi. Universitas Diponegoro, Semarang.

Satia, Y., Octorina, P., Yulperius. (2011). Kebiasaan Makanan Ikan Nila (Oreochromis niloticus) di Danau Bekas Galian Pasir Gekbrong Cianjur - Jawa Barat. Jurnal Agroqua, 9(1): 1-6.

Siregar, A.S., Sulistyo, I., Setijanto. (2007). Analisis Isi Lambung Ikan Baceman (Mystus nemurus) di Sungai Klawing, Kabupaten Purbalingga Jawa Tengah. Seminar pada Forum Perairan Umum Indonesia IV. Palembang.

(2008). Kondisi Limnologis Zona Hilir Sungai Klawing Kabupaten Purbalingga Jateng sebagai Habitat Ikan Baceman (Mystus nemurus) dan Ikan
Senggaringan (Mystus nigriceps). OMNI Akuatika, 4(7): 1-7.

Swingle, H.S. (1968). Standardization of Chemical Analysis for Water and Pond Muds. F.A.O. Fish. Rep, 44(4): 379-406.

Wardhana, W.A. (2004). Dampak Pencemaran Lingkungan. Penerbit ANDI Yogyakarta

Wardoyo, S.T.H. (1981). Kriteria Kualitas Air untuk Keperluan Pertanian dan Perikanan. Makalah Training AMDAL. Kerjasama PPH-UNDEPPUSD-PS. Bogor.

Widyastuti, E., Sukanto., Nuning, S. (2015). Pengaruh Limbah Organik terhadap Status Tropik, Rasio N/P serta Kelimpahan Fitoplankton di Waduk Panglima Besar Soedirman Kabupaten Banjarnegara. Biosfera, 32(1): 35-41.

Wulandari, D.A. (2007). Penanganan Sedimentasi Waduk Mrica. Berkala Ilmiah Teknika Keairan, 13(4): 0854 4549. 